\title{
Article \\ Assessment of Agricultural Biodiversity in Organic Livestock Farms in Italy
}

\author{
Chiara Flora Bassignana ${ }^{1}$ D , Paolo Merante ${ }^{2}$, Samanta Rosi Belliére ${ }^{3}$, Concetta Vazzana ${ }^{4}$ \\ and Paola Migliorini ${ }^{1, * \mathbb{D}}$
}

1 Agroecology Group, University of Gastronomic Science, Piazza Vittorio Emanuele, 9-Frazione, 12042 Pollenzo, Italy; c.bassignana@studenti.unisg.it

2 Independent Researcher, 37075 Göttingen, Germany; paolo.merante@gmail.com

3 ICEA, Istituto Per La Certificazione Etica Ed Ambientale, Via Giovanni Brugnoli, 15, 40122 Bologna, Italy; s.rosi@icea.info

4 DISPAA, Department of Agrifood and Environmental Science, University of Florence, Piazzale delle Cascine 18, 50144 Firenze, Italy; concetta.vazzana@unifi.it

* Correspondence: p.migliorini@unisg.it

check for updates

Citation: Bassignana, C.F.; Merante, P.; Belliére, S.R.; Vazzana, C.; Migliorini, P. Assessment of Agricultural Biodiversity in Organic Livestock Farms in Italy. Agronomy 2022, 12, 607. https://doi.org/ 10.3390/agronomy12030607

Academic Editor: David W. Archer

Received: 31 December 2021

Accepted: 25 February 2022

Published: 28 February 2022

Publisher's Note: MDPI stays neutral with regard to jurisdictional claims in published maps and institutional affiliations.

Copyright: (C) 2022 by the authors. Licensee MDPI, Basel, Switzerland. This article is an open access article distributed under the terms and conditions of the Creative Commons Attribution (CC BY) license (https:// creativecommons.org/licenses/by/ $4.0 /)$.

\begin{abstract}
Livestock farming is often addressed as one of the most impactful food production systems on the environment due to GHGE-Green-House Gas Emissions- and land use degradation. However, in the last years there is a growing number of studies that underline the beneficial environmental impacts of extensive livestock farming (i.e., providing ecosystem services, increasing biodiversity and improving carbon and nitrogen cycles), as well as social and economic benefits (i.e., offering alternative and additional forms of income in marginal areas). The multitude of livestock management approaches call urgently for specific tools of assessment in order to inform and orientate policies, farming practices and consumer choices. This study proposes a set of 14 agroecological indicators to assess the state of structural/planned agrobiodiversity in livestock farming systems. Our methodology stems from the already established Indicator-Based Framework to evaluate the sustainability of farming systems and adapted it specifically to livestock farming systems. The set of indicators has been clustered with respect to the ecosystem functions/services they describe. The methodology has been applied and validated on a selection of 12 Italian organic livestock farms and analyzed according to animal breeds and geographical regions. The results highlight that the farms show very positive results with optimal values for all indicators, except for Field Adjacency (FA), Share Species (SS), Share Group (SG). This study highlights how livestock farms could actually provide different ecosystem services in comparison to stockless farms.
\end{abstract}

Keywords: agrobiodiversity; livestock farming; agroecological indicators; ecosystem services; planned biodiversity

\section{Introduction}

\subsection{How to Evaluate the Impacts of Livestock Farming?}

Scientists, policy makers and institutions around the globe find themselves in front of what Layman [1] calls the complex trilemma of combining agricultural production with healthy diets and the protection of the environment. Landscape transformation due to agriculture affects more than $40 \%$ of the planet's land area and is the most important driver of loss of biodiversity and ecosystem services (ES) worldwide [2,3]. Livestock farming is often addressed as one of the most impactful food production systems on the environment due to GHGE -Green-House Gas Emissions- and land use degradation [1]. Intensive livestock farming directly leads to unsustainable land use, high $\mathrm{Co}_{2}$ emissions and low standards of animal welfare [2].

However, there is a growing debate around the actual impacts of livestock farming, with different studies putting forth conflicting perspectives. For instance, there is contrast- 
ing data about the actual contribution of agriculture, and specifically livestock farming, on $\mathrm{Co}_{2}$ emissions. Moreover, many studies stress how assessing livestock farming only through the metric of GHGE/kcal of food produced limits the capacity of highlighting the real impact of livestock farming on sustainability [1]. In the last years, there has been a growing number of studies that underline the beneficial environmental, social and economic impacts of livestock farming, such as providing ecosystem services, increasing biodiversity and improving carbon capture through soil and plant [4-7]. Organic livestock farming, for instance, encompasses the cultivation of legumes and leguminous grass within crop rotations, as well as stable pasture and meadows, both of which provide quality forage, alternative sources of protein and improves the soil nitrogen content through nitrogen fixation [6]. Furthermore, legumes provide ecological services including improved soil structure, erosion protection and greater biological diversity [7]. Animals mobilize and use sources of energy that are actually not edible and digestible by humans and recycle the nutrient content of plants, transforming them into manure, promoting detritus chains and offering a broader range of fertilization alternatives [3]. The distribution of animal excreta on the field either as such or composted, supplies the soil with organic matter to be decomposed and provides humus to increase soil fertility [6].

Beyond the agroecological beneficial interactions with crops, livestock farming offers alternative and additional forms of income by providing commodities (i.e., meat, milk, and fiber) and can be managed in marginal areas where it wouldn't be possible to cultivate [4] Furthermore, extensive animal husbandry (i.e., mixed farming) can play an important role in determining the biodiversity of an agroecosystem and concurs in maintaining bio-cultural landscapes (i.e., patches of forests, which are crucial for maintaining global biogeochemical cycles and biodiversity are often preserved on cattle farms, to provide shade and nutrients to animals) [8].

The multitude of livestock management approaches, each entailing completely different repercussions on the atmosphere, soil and biodiversity, calls urgently for specific tools of assessment in order to inform and orientate policy-makers, farming practices and consumer choices [9].

A variety of methodologies and set indicators have been developed in order to assess the sustainability of farming systems [10-16]; the impact of agriculture on agrobiodiversity and ecosystem services [17-21]. There have been attempts to elaborate methodology specifically addressing the sustainability of livestock farming in a more complete and inclusive way [22] for example, by incorporating agrobiodiversity within the most commonly used Life Cycle Assessment format [23,24]. Kok [24] provided a broad analysis of biodiversity assessment studies in the field of livestock farming, however most of the indicators proposed require intensive specific fieldwork analyses, that entail time and specialists to carry them out.

\subsection{Agrobiodiversity Services, Functions and Impacts}

Agrobiodiversity encompasses the variety and variability of animals, plants and microorganisms that are used directly or indirectly for food and agriculture, including crops, livestock, forestry and fisheries. It comprises the diversity of genetic resources (varieties, breeds) and species used for food, fodder, fiber, fuel and pharmaceuticals. It also includes the diversity of non-harvested species that support production (soil micro-organisms, predators, pollinators), and those in the wider environment that support agroecosystems (agricultural, pastoral, forest and aquatic) as well as the diversity of the agroecosystems [25]. Local knowledge and cultures are considered as integral components of agrobiodiversity, since agricultural human activities shape and conserve this biodiversity [25]. Zimmerer and De Hann [26] proposed that besides the sociocultural dimension, the definition of agrobiodiversity should include the economic and management sphere, as well as the level of institutional diversity.

Thousands of years of human co-evolution within different ecosystems have led to the current agrobiodiversity all over the planet. Biodiversity and agriculture are strongly 
interrelated: biodiversity is essential for a vital and nourishing agriculture that provides food security and adequate nutrition, whereas sustainable agriculture can actually sustain and promote local biodiversity [9].

Overmars [27] underlines the importance of agrobiodiversity as a public good that provides ecosystem services necessary for the sustainability of agriculture itself as well as for a sustainable environment as a whole.

According to Vandermeer [28], two distinct components of biodiversity can be recognized in agroecosystems: (i) the planned or structural biodiversity, which refers to the biodiversity related to the crops and livestock purposely included in the agroecosystem by farmers and which will vary depending on the management inputs and crop spatial/temporal arrangements; (ii) the associated biodiversity which covers all soil flora and fauna, herbivores, carnivores, decomposers, etc. that colonize the agroecosystem from surrounding environments and that will thrive within the agroecosystem according to its management and its structure. This study is focused on planned biodiversity. Planned biodiversity plays a dual role in the ecosystem, by directly promoting ecosystem functions (e.g., pest regulation, nutrient cycling, etc.) and creating conditions for the presence of associated biodiversity that, in turn, will promote further ecosystem functions [11,15]. Ecosystem services have been defined by Daily [29] as the conditions and processes through which natural ecosystems, and the species that make them up, sustain and fulfil human life. Ecosystem services are the set of ecosystem functions that are useful to humans. The services provided by agrobiodiversity, affect human well-being through provisioning services such as food, water, timber, and fiber; regulating services such as the regulation of climate, floods, disease, wastes, and water quality; cultural services such as recreation, aesthetic enjoyment, and spiritual fulfillment; and supporting services such as soil formation, photosynthesis, and nutrient cycling [30].

Agrobiodiversity has declined steeply during the past 100-150 years, threatened by increasing global climate change and food system transformations, with concerns mounting over the decline of critical agrobiodiversity and entwined sociocultural systems [26]. Losing agrobiodiversity entails the loss of the ecosystem services connected to it [31]. Therefore, it is crucial to develop and validate adequate indicators and methodologies to assess biodiversity in agricultural landscapes [27].

Numerous studies have analysed the several beneficial impacts of planned agrobiodiversity at the environmental and landscape level as well as on the biocultural, nutritional and socio-economic spheres both locally and on a wider scale [26,32]. Planned agrobiodiversity can contribute to efficiency in the use of available resources, the quality of human nutrition [33,34], the reduction of the risk of pests and diseases, the enhancement of soil health and fertility [35], the preservation of genetic resources and securing food supply and economic profit [36].

However, most of the methodologies are focused on the assessment of associated biodiversity and not in particular on planned agrobiodiversity. Therefore, this study aims to provide an innovative set of agroecological indicators, that can be easily implemented, to assess the state of structural/planned agrobiodiversity in livestock farming systems.

\section{Materials and Methods}

\subsection{Planned Biodiversity Indicators}

For the evaluation of the structural/planned biodiversity an established methodology developed since 1997 was adapted [17,19,37-39]. The set of 14 indicators has been clustered with respect to the ecosystem functions/services they describe (Table 1), as suggested by Altieri [40], and on specific farm drivers. The farm drivers refer to those farm management aspects that contribute to determine the biodiversity associated with crops and livestock included in the agroecosystems and managed by farmers, which in turn affect the performance of specific ecosystem functions. Accordingly, five indicators groups were identified, as follows: 
- Farm cultivated land;

- Natural and wild land;

- Plant coverage;

- Crop rotation composition;

- $\quad$ Livestock.

Table 1. Planned biodiversity: drivers, indicators, ecosystem services and functions.

\begin{tabular}{|c|c|c|c|c|c|c|}
\hline & Farm Drivers & & Indicators & Symbol & Functions & Ecosystem Services \\
\hline a. & $\begin{array}{l}\text { Farm cultivated } \\
\text { land }\end{array}$ & $\begin{array}{l}1 . \\
2 . \\
3 . \\
4 .\end{array}$ & $\begin{array}{l}\text { Field Adjacency } \\
\text { Crop field size } \\
\text { Field Length/Width } \\
\text { Field density }\end{array}$ & $\begin{array}{l}\text { FA } \\
\text { CFS } \\
\text { FLW } \\
\text { FD }\end{array}$ & $\begin{array}{l}\text { Population regulation, Pest } \\
\text { control, Biological control } \\
\text { and Pollination }\end{array}$ & REGULATING \\
\hline b. & $\begin{array}{l}\text { Natural and } \\
\text { Wild Land }\end{array}$ & $\begin{array}{l}5 . \\
6 .\end{array}$ & $\begin{array}{l}\text { Wood Farm Area } \\
\text { Ecological Infrastructure } \\
\text { Index }\end{array}$ & $\begin{array}{c}\text { WFA } \\
\text { EII }\end{array}$ &  & $\begin{array}{c}\text { PROVISIONING } \\
-{ }_{-}----- \\
\text {REGULATING } \\
\text { CULTURAL }\end{array}$ \\
\hline c. & Plant Coverage & $\begin{array}{l}7 . \\
8 .\end{array}$ & $\begin{array}{l}\text { Annual Soil Cover Index } \\
\text { Critical Period Soil Cover } \\
\text { Index }\end{array}$ & $\begin{array}{l}\text { SCIa } \\
\text { SCIC }\end{array}$ & $\begin{array}{c}\text { Soil stability and structure } \\
\text { (soil erosion) } \\
\text { Soil fertility (OM formation, } \\
\text { Nutrient cycling) }\end{array}$ & REGULATING \\
\hline d. & $\begin{array}{l}\text { Crop Rotation } \\
\text { Composition }\end{array}$ & $\begin{array}{l}9 . \\
10 . \\
11 . \\
12 .\end{array}$ & $\begin{array}{l}\text { Crop Diversity } \\
\text { Crop Rotation } \\
\text { Share Species; Share } \\
\text { Group } \\
\text { Share Leguminous; Share } \\
\text { Cereals }\end{array}$ & $\begin{array}{l}\text { CD } \\
\text { CR } \\
\text { SS } \\
\text { SG } \\
\text { SL } \\
\text { SC }\end{array}$ & $\begin{array}{c}\text { Food (legumes, cereals, etc.) } \\
\text { Söil fertility } \overline{(\overline{O M} \text { formation, }} \\
\text { Nutrient cycling) } \\
\text { Aesthetic }\end{array}$ & $\begin{array}{c}\text { PROVISIONING } \\
-------- \\
\text { REGULATING } \\
\text { CULTURAL }\end{array}$ \\
\hline e. & Livestock & $\begin{array}{l}13 . \\
14 .\end{array}$ & $\begin{array}{l}\text { Animal Unit on the Farm } \\
\text { Number of Breeds }\end{array}$ & $\begin{array}{l}\text { AUF } \\
\text { BN }\end{array}$ & 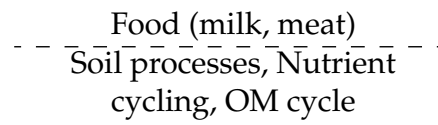 & $\begin{array}{c}\text { PROVISIONING } \\
-\bar{R} \overline{\mathrm{E}} \overline{\mathrm{G}} \overline{\mathrm{UL}} \overline{\mathrm{A}} \overline{\mathrm{TI}} \overline{\mathrm{N}} \overline{\mathrm{G}} \\
\text { CULTURAL }\end{array}$ \\
\hline
\end{tabular}

\section{a. Farm cultivated land}

Indicators of this group provide information about the spatial distribution and size of the farm's cultivated fields. Farm's fields with appropriate size and adequately spatially distributed over the farm area can greatly contribute to agrobiodiversity by promoting the creation of habitats and corridors for insects that, in turn, can actively contribute, for instance, to pollination, population regulation and to the biological control and thus to primary production support.

1. Field Adjacency (FA): The farm is defined as the legal/economic unit owned or rented by the farmer. Spatially, farm fields are not necessarily adjacent to each other but can be quite far apart, depending on the historical evolution of farming in the region in question [41]. Rather than lying adjacent to one another, in many instances the fields of an individual farm may be separated by other farmers' fields, or by land put to non-agricultural use. In most situations, therefore, a farm does not constitute a cohesive ecological unit. However, in order to reach an ecological integrity and resilience within the agroecosystem that works as a functional unit, the fields have to lie next to each other following the concept of "habitat fragmentation" and "connectivity" that is the measure of how connected or spatially continuous a corridor, network, or matrix is [42]. Moreover, in organic farms, according to the European standards [43], each field neighbouring with a conventional farm is considered at risk in terms of contamination of pollutants, hence certification bodies 
request farmers to build ecological barriers (herbaceous strips, arboreal fence) to reduce the risk of chemical drift.

$$
\mathrm{FA}=\frac{\sum_{1}^{\mathrm{n}} \frac{\mathrm{N} \text { Field } \times \text { Unit }}{\text { Tot. Field }}}{\mathrm{n}}
$$

where: "number of fields per unit" are the numbers of fields that represent a unit (either adjacent or isolated); "Tot. Field" is the tot numbers of fields; "n" stands for the number of units of fields. The optimal value is equal to one, which happens when all parcels are adjacent to each other $(\mathrm{n}=1)$ [42].

2. Crop Field Size (CFS): the field size gives indications on the structural biodiversity. The concepts related to ecological units, such as population, community, and ecosystem, are at the basis of ecological theory and research and have increasingly become the focus of conservation strategies $[44,45]$. The desired value of the unit size considered in our framework is minimum one hectare, since the fields have to be large enough to be considered an ecological unit $[44,45]$.

3. Field Length-Width (FLW): the field structure gives indications on structural biodiversity and it contributes to the ecological identity of the farming system. Round or squared fields are considered optimal [46] as they offer an equal distance from the centre of the field to the perimeter, allowing for an homogenous pest control, nutrient and water cycle in the crop field and where ecological infrastructures and buffer strips are present (representing habitats for beneficial insects) [31]. A field should be homogenous in terms of spatial organisation and processes carried out in order to influence associated biodiversity in the same way. The desired value is between 1 and 4 .

4. Field Density (FD): expresses the ratio between the field number and UAA (Utilised Agricultural Area). The higher the number of the fields in a farm, the higher is the possibility to have field margins (herbaceous strips, flowering shrubs and hedges) that may act as natural corridors hosting beneficial insects $[17,46,47]$. The desired value of this indicator is the maximum possible. According to landscape ecology, high field density provides more ecotones that improves landscape both under a functional (i.e., influences of spatial heterogeneity on biotic and abiotic processes as an example of spatial patterns) and aesthetic point of view [46].

\section{b. Natural and Wild Land}

These indicators concern areas that, although belonging to the farm, are not directly affected by crop cultivation or animal husbandry [48] and require little agronomic management. These areas provide marketable products such as wood and freshwater. Moreover, they ensure species diversity (flora and fauna) and interrelations between species through the presence of natural habitats [49]. These areas, thus, provide genes from crop wild relatives which are important for improving performance in the future with adaptation of cultivated species i.e., climate change resilience [50]. In addition, they regulate microclimate, disease, and water quantity (flood) and quality (purification). Finally, they offer cultural services (Aesthetic, Spiritual, Educational, Recreational) [51].

5. Wood Farm Area (WFA): it indicates the level of balance between the agricultural land and the wood area. The presence of a forestry area is pivotal both for ecological function of the natural enemies reservoir (population regulation and biological control) and for landscape diversification and production. The trees, then, create shade (direct function) and attract beneficial insects (indirect function). Moreover, if there are corridors of natural vegetation linking the forest area with agricultural land, it provides an ecosystem function of resource conservation and regeneration (soil, water, wildlife).

$$
\text { WFA }=\frac{\sum \text { Woodland }}{\text { Farmland }} \times 100
$$

where Woodland refers to the surface (in ha) covered by woods, Farmland is the total farm surface. 
A farm woodland equal to or greater than $10 \%$ of the total farm area can be considered an optimal value as demonstrated by other studies performed on Italian farms [17].

6. Ecological Infrastructure Index (EII): farm area covered by both natural/untouched and planted/managed herbaceous, shrubs and tree vegetation, that can serve as natural habitats and corridors (Ecological infrastructures) for agroecological and landscape purposes.

$$
\mathrm{EII}=\frac{\sum \text { Ecol. Infr. Area }}{\mathrm{UAA}}
$$

It is considered as a desirable value that the farmland devoted to the ecological infrastructure is greater than or equal to 5\% of the Utilized Agricultural Area (UAA) [50].

\section{c. Plant coverage indexes}

Plant coverage, in terms of crop and crop residues, can greatly contribute in supporting soil processes, in preventing soil loss due to water runoff and wind, in particular in the rainiest seasons. Moreover, a continuous succession of crops contributes to the soil forming structure, stability and nutrient cycling (mineralisation and uptake), especially when the related residues are properly managed. Moreover, the soil cover increases the organic matter decomposition (mineralisation process) and formation (humification process). To this regard, the following indicators refer to the $\%$ of surface covered by crops and crop residues over the year.

7. Annual Soil Cover Index (SCIa): the soil cover index of the crop is measured on a monthly basis as an annual average of coverage for soil erosion caused by water and wind.

$$
\mathrm{SCI}=\frac{\sum_{1}^{12} \frac{\mathrm{SCli}+\mathrm{SCIf}}{2}}{12}
$$

where SCIc is the Soil Cover Index of a single crop on an annual basis (12 months), while SCli and SClf refer to the monthly Soil Cover (in \%) of that crop at the beginning of the month (i) and at the end (f) respectively.

The SCIa of the whole crop rotation is measured as a weighted average value of the area covered by crops or crop residues during the year.

$$
\text { SCIa }=\frac{\sum_{1}^{\mathrm{n}} \text { SCIc } \times \text { Area }}{\sum_{1}^{\mathrm{n}} \text { Area }}
$$

The optimal value considered for this indicator is higher than $50 \%$ of the months in one year.

8. Critical period Soil Cover Index (SCIcp) is the average of the period (in months) considered critical for soil erosion caused by heavy water and frequent wind. In temperate climates, the critical period is considered the one going from November to April (6 months). The SCIcp of crop rotation is measured as a weighted average value of SCICcp of the single crop for the area covered by crops or crop residues.

$$
\begin{gathered}
\text { SCICcp }=\frac{\sum_{1}^{6} \frac{\text { SCIi }+ \text { SCIf }}{2}}{6} \\
\text { SCIcp }=\frac{\sum_{1}^{\mathrm{n}} \text { SCIc } \times \text { Area }}{\sum_{1}^{\mathrm{n}} \text { Area }}
\end{gathered}
$$

The desired value considered for this indicator is higher than $60 \%$ of the months in one year.

\section{d. Crop rotation composition}

By species diversity of grown crops and their temporal and spatial distribution over the cropping season, a farm can significantly contribute to the planned biodiversity thus supporting multiple specific ecosystems functions such as: food provisioning, disease regulation (population regulation and the biological control) and supporting soil processes 
such as forming soil structure and stability, nutrient cycling (mineralisation and uptake), organic matter decomposition and formation [50]. Furthermore, the landscape benefits from a proper soil cover and thus provides cultural and aesthetic services as well. Indicators of this group take into consideration both the crop diversity at farm level and the one occurring within the crop rotations as planned by farmers.

9. Crop diversity $(C D)$ : this indicator counts the number of species cultivated in the farm (herbaceous, arboreal, cash crop or green manure). It expresses species diversity in the crop rotation and gives a good indication of the planned biodiversity. Crop diversity is one pillar of agroecological diversification strategies [8,40] to break monoculture and help to enhance beneficial fauna, recycling of biomass and balance nutrient flow [52]. The desired value of this indicator is the maximum possible.

10. Crop Rotation (CR): Crop diversity in space and time is the base for sustainable agriculture. The crop rotation of farming systems is defined in relation to many factors like environment, climate, soil, resources, market $[48,52]$. The duration of the crop rotation refers to the number of years it takes for a specific crop to be grown again in the same field. In large farms with more than one cropping system we consider the mean value. In organic certification the minimum crop rotation is 3 year including a leguminous crop. However, the desired value is more than 6 years as some methodologies suggest [8].

11. Share Species (SS) and Share Group (SG): They indicate the percentage of certain species and botanical groups within the crop rotation. The prevalence of a species or group has to be limited [48] to avoid homogeneity. The indicator groups all the homogeneous species in genetic and phytopathological terms together (i.e., cereals, solanaceae, brassicaceae).

The calculation is done in two phases: first we calculate the presence of single species SSi (8) and group SGi (9) in the year; and then for the whole cropping systems (10) and (11).

$$
\begin{aligned}
S S i & =\frac{\frac{M c}{12}}{\frac{\sum_{1}^{n} M c}{12}} \\
S G i & =\frac{\frac{M g}{12}}{\frac{\sum_{1}^{\mathrm{n}} M g}{12}}
\end{aligned}
$$

where Mc (n) is the number of months of presence of the crop, $\mathrm{Mg}(\mathrm{n})$ is the number of months of presence of the crop group, $n$ is the number of these crops in the rotation, $\mathrm{i}$ is the single species in the rotation.

The percentage of species of the whole crop rotation, SS, is calculated as a weighted average of the areas of individual SSi.

$$
\begin{aligned}
\mathrm{SS} & =\frac{\sum_{1}^{\mathrm{n}} \mathrm{SSi} \times \text { Area }}{\sum_{\mathrm{i}}^{\mathrm{n}} \text { Area }} \\
\mathrm{SG} & =\frac{\sum_{1}^{\mathrm{n}} \mathrm{SGi} \times \text { Area }}{\sum_{\mathrm{i}}^{\mathrm{n}} \text { Area }}
\end{aligned}
$$

The desired values of the indicator Share Species is therefore $x<0.167$ since 0.167 stands for one sixth of a crop rotation of six years. The desired value of the indicator Share Group is $x<0.33$ since 0.33 represents one third of a rotation of three years of species groups.

12. Share Leguminous (SL) and Share Cereals (SC): These two indicators stem from the two previous ones but they specifically indicate the percentage of respectively leguminous and cereal crops within the crop rotation. Their value highlights the presence of these kinds of plants and their contribution to ecosystem services in the farms. Leguminous crops we choose the maximum value that is equal 0.33 following the regulation of organic farming and soil fertility enhancement [43]. 


\section{e. Livestock}

The integration of crop farming with livestock rearing leads to mixed farming systems which involve a considerable crop diversity due to the inclusion, within the crop rotations, of forage crops (especially legumes), pasture and meadows. Livestock, besides being the source of alternative marketable products (provision of food), which could create a more stable income for farmers, provide farms with organic fertilizers (i.e., manure and slurry), which in turn can notably support soil processes (soil forming structure and stability, nutrient cycling, organic matter decomposition and formation). As a consequence of good soil structure and presence of permanent pasture, livestock can regulate floods [48]. Nevertheless, in order to avoid negative consequences, such as overgrazing, (that in turn would increase soil loss and soil compaction) and an overconcentration of nutrients, (e.g., nitrogen that would be leached), the animal stock must be balanced with the available farmland.

13. Animal Unit on the Farm (AUF): is the ratio of livestock present on the farm, expressed in Livestock Unit (LU), calculated by conversion coefficient [53], over the Utilized Agricultural Area (UAA).

$$
\mathrm{AUF}=\frac{\mathrm{LU}}{\mathrm{UAA}}
$$

It must be less than two as required by the regulations in organic farming. It is considered an important aspect for planned biodiversity in livestock farms because the animal density directly influences the biomass consumption and the soil structure and nutrient cycling (Table 2).

Table 2. List of the selected Indicators and their desired values.

\begin{tabular}{|c|c|c|c|c|}
\hline & Indicator & Acronym & Unit & Desired Values \\
\hline 1. & Field Adjacency & FA & number & $x=1$ \\
\hline 2. & Crop Field Size & CFS & На & $x>1$ \\
\hline 3. & Field Length/Width & FLW & Number & $1<x<4$ \\
\hline 4. & Field Density & FD & Number$^{*} \mathrm{ha}^{-1}$ & $\max$ \\
\hline 5. & Wood Farm Area & WFA & $\%$ SAT & $x>10$ \\
\hline 6. & Ecological Infrastructure Index & EII & $\% S A U$ & $x>5$ \\
\hline 7. & Annual Soil Cover Index & SCIa & $\%$ months & $x>50$ \\
\hline 8. & Critical Period Soil Cover Index & SCIc & $\%$ months & $x>60$ \\
\hline 9. & Crop Diversity & CD & Number*ha $^{-1}$ & $x>6$ \\
\hline 10. & Crop Rotation & CR & Years & $x \geq 6$ \\
\hline 11a. & Share Species & SS & $\%$ tot. species & $x \leq 0.167$ \\
\hline $11 b$. & Share Group & SG & $\%$ tot. group & $x \leq 0.33$ \\
\hline 12a. & Share Group Leguminous & SGL & $\%$ tot. leg & $x=0.33$ \\
\hline $12 b$. & Share Group Cereals & SGC & $\%$ tot. leg & $x \leq 0.33$ \\
\hline 13. & Animal Unit on the Farm & AUF & $\mathrm{UBA}^{*} \mathrm{ha}^{-1}$ & $x<2$ \\
\hline 14. & Number of Breeds & $\mathrm{BN}$ & Number & $\max$ \\
\hline
\end{tabular}

14. Number of Breeds (NB): is the total number of breeds present in the farm. This indicator provides an overview on the biodiversity in terms of breeds present and about the geographical provenance of the breeds. The optimal value is the highest possible. 


\subsection{Assessment of Agrobiodiversity in Livestock Farms}

The assessment of the agricultural biodiversity in livestock farms was performed by comparing each planned biodiversity indicator with the related desired value (Table 2), namely the threshold that must be achieved in order to declare optimal a specific farm performance.

Set of indicators has been tested using an assessment of structural/planned agrobiodiversity on 12 organic livestock farms that have collaborated in the Italian inter-regional research project Equizoobio "Efficiency, quality and innovation in organic livestock production" (http:/ / www.equizoobio.it/, 14 December 2021). The data was collected in June 2005 through several surveys carried out over a 1 year period, following a semi-structured questionnaire. Researchers and farmers jointly completed forms about farming systems management during the field survey. A secondary interview round has been conducted in 2021 to update the data and track the changes 16 years later. The methodology can be applied to any typology of livestock farming systems. However, the scenario is for farming activities that enhance ecological services and agrobiodiversity. We tested the methodology in a set of organic farms in order to unveil if organic livestock standards are sufficient to fulfill optimal results in agrobiodiversity.

Furthermore, the values of the indicators have been compared with those included in the sustainability score for stockless farms developed by Migliorini [54] in order to better identify how the set of indicators can highlight the contribution of livestock farming systems to agrobiodiversity and ecosystem services.

\subsection{Case Studies}

The farms were identified in each region by local technicians and organic farming associations and were selected in consultation with members of research teams based on following criteria: (i) they applied organic methods since a long time (more than 10 years); (ii) they should be managed with a low external input regime and with an agroecological approach [8]; (iii) farms should be representative in each region of different livestock sectors. In total 12 livestock farms cultivating grain-forage crops were selected, located in 9 regions of northern (Piedmont and Emilia-Romagna), central (Tuscany, Marche and Lazio) and southern Italy (Basilicata, Puglia, Campania and Sicily). The analysed farms (Table 3) were grouped according to four productive sectors: cattle beef, dairy cattle/buffalo, dairy sheep and pig. Most of the selected organic farms raise quality breeds in terms of their productive and local, gastronomic characteristics as, for instance, high-quality milk and PDO buffalo mozzarella cheese (Protected Designation of Origin according to EU, 2012), many of these products are sold through short supply chains or direct sale on farms. These conditions are not the only ones to apply the methodology. However, to validate it we considered crucial to compare similar farming systems. Moreover, in this study, we chose cases that could be repesentative of the Italian livestock sector, to highlight the differences among regions (north, centre and south) and productive sectors (cattle beef, dairy cattle/buffalo, dairy sheep and pig).

Table 3. Structural data of 12 farms divided by productive system and zone.

\begin{tabular}{ccccc}
\hline $\begin{array}{c}\text { Productive or } \\
\text { Geographical Sector }\end{array}$ & n. Farms & $\begin{array}{c}\text { Average Total Farm's } \\
\text { Land (ha) }\end{array}$ & $\begin{array}{c}\text { Average Agricultural } \\
\text { Farm's Land (ha) }\end{array}$ & $\begin{array}{c}\text { Average n. Animal } \\
\text { (Main Species) }\end{array}$ \\
\hline $\begin{array}{c}\text { Cattle beef } \\
\text { Dairy Cattle/buffalo }\end{array}$ & 4 & 273.95 & 250.22 & 131.5 \\
Dairy sheep & 3 & 200.08 & 122.04 & 346.67 \\
Pig & 4 & 115.02 & 97.5 & 387.5 \\
\hline North & 1 & 44.85 & 38.25 & 205 \\
Centre & 3 & 35.28 & 28.92 & 131 \\
South & 5 & 241.76 & 149.66 & 359.8 \\
\hline
\end{tabular}




\subsection{Statistical Considerations}

In order to better underline the comparison, the indicator value is transformed in relative shortfall (discrepancy) of achieved (A) to desired (D) results according to the following formula: (A-D)/D. Discrepancy values can result between 0 and 1 . The maximum total discrepancies that could achieve each farm is $14(14 \times 1)$ and that could happen in case one farm, for all the 14 indicators, reaches a value very far from the desired results.

To highlight the differences between the four production systems (cattle beef, dairy cattle, dairy sheep and pigs) and the three zones (north, central and southern Italy), the indicator's shortfalls are calculated by combining the averages of the results.

Differences between treatments (production systems and production zones) were tested using an analysis of variance (ANOVA) and mean comparisons were evaluated by the Bonferroni test (SPSS 28 software).

\section{Results}

Our analysis suggests that the farms included in the study can be described as multifunctional farms as they cultivate cereal and fodder crops with the presence of permanent pasture for animal feeding, but they also practice horticulture and viticulture, as well as other diversified activities connected to agriculture such as direct sales and agro-tourism.

The farm structure analysis (Table 3), shows that the cattle beef farms are the largest compared to the other typologies, and that the farms located in Northern Italy have total and agricultural area eight times smaller than the ones located in Southern and Central Italy.

The values reached by each indicator and its relative standard deviation are shown in Table 4, as an average of the twelve case studies.

The table also presents the values of the indicators applied to stockless farms in the study of Migliorini [54], for a further comparison in the use of the set of indicators with stockless farms as well.

Table 4. List of agroecological indicators, acronyms, optimal value, achieved value and standard deviation from the average of 12 case studies.

\begin{tabular}{|c|c|c|c|c|c|c|}
\hline Indicators & Acronyms & u.m. & $\begin{array}{c}\text { Desired } \\
\text { Value (D) }\end{array}$ & $\begin{array}{l}\text { Achieved } \\
\text { Value (A) }\end{array}$ & $\begin{array}{l}\text { Standard } \\
\text { Deviation }\end{array}$ & $\begin{array}{l}\text { Stockless } \\
\text { Indicators }\end{array}$ \\
\hline Field Adjacency & FA & number & $x=1$ & 0.39 & 0.24 & - \\
\hline Crop Field Size & CFS & hectare & $x>1$ & 4.71 & 3.38 & - \\
\hline Field Length/Width & FLW & number & $1 \leq x \leq 4$ & 2.64 & 0.63 & 4.91 \\
\hline Field Density & FD & Number*ha $^{-1}$ & $\max$ & 0.28 & 0.22 & 3.62 \\
\hline Wood Farm Area & WFA & $\%$ Tot Land & $x>10$ & 19.46 & 15.64 & 3.99 \\
\hline Ecological Infrastructure Index & EII & $\%$ Agr. Land & $x>5$ & 26.41 & 34.96 & 16.68 \\
\hline Annual Soil Cover Index & SCIa & $\%$ months & $x>50$ & 64.38 & 23.15 & 89.45 \\
\hline Critical period Soil Cover Index & SCIc & $\%$ months & $x>60$ & 84.57 & 14.96 & 78.32 \\
\hline Crop Diversity & CD & number & $x \geq 6$ & 7.33 & 3.68 & 6.00 \\
\hline Crop Rotation & CR & years & $x \geq 6$ & 6.06 & 2.66 & 6.00 \\
\hline Share Species & SS & $\%$ tot. species & $x \leq 0.167$ & 0.28 & 0.09 & 0.07 \\
\hline Share Group & SG & $\%$ tot. group & $x \leq 0.33$ & 0.43 & 0.09 & 0.18 \\
\hline Share Species Leguminous & SSL & $\%$ tot. leg & $x=0.33$ & 0.43 & 0.23 & - \\
\hline Share Species Cereals & SSC & $\%$ tot. cer & $x \leq 0.33$ & 0.53 & 0.23 & - \\
\hline Animal Unit on the Farm & AUF & $\mathrm{LU}^{*} \mathrm{ha}^{-1}$ & $x<2$ & 1.42 & 0.76 & 0 \\
\hline Number of Breeds & NB & number & $\max$ & 1 & 0 & - \\
\hline
\end{tabular}

Biodiversity assessment of all the farms grouped together shows very positive results (Table 4). Indeed, the values of all indicators enter in the optimal range value, except for Field Adjacency (FA), Share Species (SS), Share Group (SG). The assessment shows that the fields are not always adjacent (0.39) and this is not a positive fact as it cuts off the ecological unit of the organic farm (optimal value is 1). However, the size of the fields and their composition are balanced as shown by the value of the indicator of Field length/width. 
The assessed presence of woodland in the farms' land is very large $(19.46 \%)$ and farms appeared to be extremely rich in ecological infrastructures $(26.41 \%)$ with much higher values than the optimal one (respectively $10 \%$ and $5 \%$ ), therefore all farms result to be rich in natural areas. The duration of crop rotation (CR) is over 6 years, showing that these farms adopt large plans. The percentage of species and groups (Share Species and Share Groups) is unbalanced due to the large presence of cereals (mainly barley and maize which together represent $52 \%$ of all crops), necessary to satisfy the energetic needs of animal feeding and of leguminous species (meadows and pastures, grass and alfalfa represent $43 \%$ of total group).

The soil cover, both in the annual period $(68.38 \%)$ and during the critical period $(84.57 \%)$, is well above the optimum value (respectively $50 \%$ and $70 \%$ ), showing a good management of soil fertility against soil erosion.

The analysis of the results through the discrepancies between production systems and production zones is displayed in the amoeba graph. The ANOVA did not highlight statistically significant differences between the indicators grouped per production zones (North, South and Centre) and production sectors (dairy cattle, cattle beef, dairy sheep and pig). Even though the total values of discrepancy are very low, the analysis showed some differences (Figures 1 and 2).

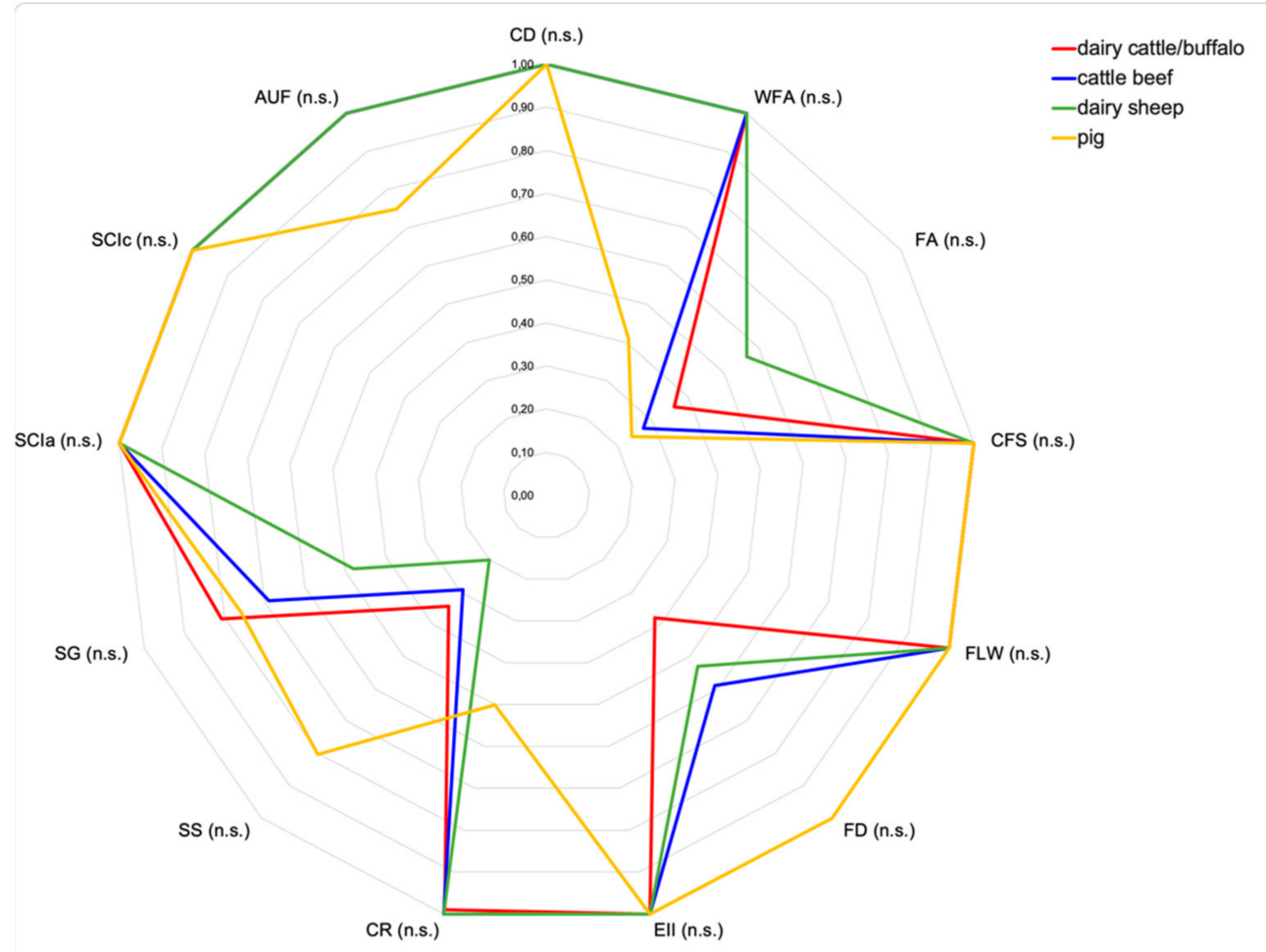

Figure 1. Discrepancy of the indicators' values between production sectors.

The Share species indicator presents the higher discrepancy between the farms grouped in the North, Centre and South of Italy, as illustrated in Figure 2. The average value of Share species for the farms analyzed in the North of Italy is equal to zero (Figure 2).

In particular, regarding the type of production, dairy cattle farms show minor discrepancies in total (2.12) than the other farm types, followed by cattle beef (2.65), dairy sheep (3.36) and pig (3.31). The higher discrepancies shown by the pig farm are attributed to the indicators Crop Rotation (CR) and Wood Farm Area (WFA), that do not reach the optimum values while are within the threshold values for the other livestock groups. Moreover, the higher discrepancies are displayed to Share Species in cereals (SSC) and in leguminous (SSL) as dairy cattle farms have a large proportion of leguminous crop while others, pigs in particular, cultivate mainly cereals for concentrates. 




Figure 2. Discrepancy of the indicators' values between geographical zones.

The values of the chosen indicators have been compared with the indicators included in the sustainability score indicators developed by Migliorini et al. in 2018. The comparison had been possible only between the indicators shared in both studies.

The comparison showed how the set of indicators can highlight differences in the two farming systems and therefore suggest how they contribute differently to agrobiodiversity. Livestock farms included in our study showed better values for the indicators of wood area, ecological infrastructure and crop diversity. Wood/wild farm area, where the desired value should be more than 10 , in stockless farms reached the value of 3.99 , while in livestock farms 19.46.

The ecological infrastructure index for both farm systems reached desired values since they both showed values higher than 5 , but livestock farms presented a much better result with 26.41 in comparison to stockless farms reaching only at 16.68 .

Eventually, the indicator of crop diversity where the desired value should be equal or higher to 6, stockless farms reached just 6, while livestock farms reached 7.33.

Table 5 illustrates the changes highlighted in the farms under study after a time span of 15 years. We could observe that several farms actually increased the number of species and breeds present in the farm. While others decreased the number of animals and breeds. The ecological infrastructures at farm level appeared to be quite stable. In contrast several farms increased the agricultural production of feed, two in particular reached $90 \%$ and $100 \%$ of self-production of feed. 
Table 5. Agrobiodiversity trends 2006-2021 of the different farms under study.

\begin{tabular}{|c|c|c|c|}
\hline Case Studies & Livestock & $\begin{array}{l}\text { Agrobiodiversity Trends } \\
\text { 2006-2021 }\end{array}$ & Main Aspects \\
\hline a & $\begin{array}{l}\text { Dairy } \\
\text { Sheep }\end{array}$ & 仓 & $\begin{array}{l}\text { Adoption of more breeds and different livestock species (pigs, } \\
\text { bees and dairy cattle); increased the self-production of cereals } \\
\text { and leguminous }\end{array}$ \\
\hline $\mathrm{b}$ & $\begin{array}{l}\text { Dairy } \\
\text { Sheep }\end{array}$ & $\sqrt{2}$ & $\begin{array}{l}\text { Changed the local breed for a foreign one. Decreased } \\
\text { the production }\end{array}$ \\
\hline c & $\begin{array}{l}\text { Dairy } \\
\text { Sheep }\end{array}$ & - & We couldn't reach the farm \\
\hline $\mathrm{d}$ & $\begin{array}{l}\text { Dairy } \\
\text { Sheep }\end{array}$ & $\widehat{\widehat{1}}$ & $\begin{array}{l}\text { Kept the local breed. Increased the agricultural production: } \\
\text { nowadays the produce } 100 \% \text { of the feed themselves }\end{array}$ \\
\hline e & Pig & $\Rightarrow$ & $\begin{array}{l}\text { Changed the pig farm in Cattle beef but kept growing the feed } \\
\text { for the animals themselves }\end{array}$ \\
\hline $\mathrm{f}$ & $\begin{array}{l}\text { Dairy } \\
\text { Buffalo }\end{array}$ & $\Rightarrow$ & Same breed, same number of animals. Same organization \\
\hline $\mathrm{g}$ & Dairy cattle & - & $\begin{array}{l}\text { The farm has been incorporated into another organic } \\
\text { cooperative in the area }\end{array}$ \\
\hline $\mathrm{h}$ & Dairy cattle & 仓 & $\begin{array}{l}\text { Adopted a new local breed, increased the agricultural } \\
\text { production of the feed, } 90 \% \text { of which is produced in the farm }\end{array}$ \\
\hline i & Cattle Beef & Ð & $\begin{array}{l}\text { Increased the number of breeds and species. Increased the } \\
\text { production of feed. }\end{array}$ \\
\hline $\mathrm{j}$ & Cattle Beef & $\sqrt{2}$ & $\begin{array}{l}\text { Not anymore practicing organic agriculture, increased the } \\
\text { production and number of animals but decreased the number } \\
\text { of breeds }\end{array}$ \\
\hline $\mathrm{k}$ & Cattle Beef & $\Rightarrow$ & $\begin{array}{l}\text { The farm kept the same number of animals and breeds, as well } \\
\text { as same organization }\end{array}$ \\
\hline
\end{tabular}

\section{Discussion}

The set of indicators presented in this paper aims to provide a methodological framework to assess the structural or planned agrobiodiversity of different types of livestock farming systems.

We adapted the aforementioned framework specifically to livestock farming systems, elaborating a methodology that allows agrobiodiversity to be assessed in these contexts in a relatively fast way. The methodology presented requires to be carried out by an experienced researcher but can rapidly provide reliable results. Moreover, a relatively small amount of data is required for the assessment and can be acquired by interviews and map acquisition, without requiring any lab analysis.

We elaborated a framework that combines the selected set of indicators with associated ecosystem services. The methodology we presented has been tested and validated on a set of case studies including different types of organic livestock systems across the Italian peninsula. The choice of constraining some in depth elements has been made in order to maintain the agile nature of the methodology for instance the framework doesn't include the performance of Shannon Index or Braun Blanquet classification, since both the methodologies would have led to a much longer time of assessment. Moreover, the set of indicators can be easily implemented with additional indicators that could deepen certain aspects such as for instance animal welfare, that hasn't been included so far, since the primary objective of our methodology was to capture the agricultural biodiversity of livestock farms. 
The proposed methodology can be improved in several aspects: first, the relationships of the farms with the surrounding landscape vary a lot, depending on key factors such as the built infrastructure (access roads, electrification), proximity to urban centers and the co-existence with other farms. These variables have not been included in this document but remain to be explored in further studies, in particular the relationship of the major agroecosystem with neighboring farms.

This is the reason why we have chosen to value the farms that show an ecological unit with the Farm cultivated land indicators (n.1-4). In fact, the internal relationships of agrobiodiversity change in respect to farm dimensions. These changes should be also explored, due to the size of the agroecosystems that may affect the movement and action of many living organisms. However, this is not a failure of the methodology itself being this a challenge of agroecology as a science.

Our study identified the analyzed farms as mixed and multifunctional farms. Great agrobiodiversity and variation in time and space differentiate the mixed farms from specialized farms. The degree of internal regulation of agroecosystems is largely dependent on the level of plant and animal diversity, and the variation resulting from structural/planned biodiversity should influence the functional one at multiple spatial and/or temporal scales in order to maintain ecosystem services that provide critical inputs to agriculture, such as soil fertility, pest and disease control, water use efficiency, and pollination [36,44].

We tested our methodology on organic livestock farms to unveil differences of agrobiodiversity among homogeneous production management systems, since some of the parameters we included in the set of indicators do not constitute the minimum threshold requirement for organic certification-as for instance the presence of ecological infrastructure. The limited number of samples do not allow us to provide any conclusions regarding the experimental factors (production type and geographical area) at farm levels. However, we consider this a good sample of farms to test the indicators.

The indicator field adjacency didn't emerge as always satisfied parameter, in the organic farms under study; this result doesn't represent a positive outcome for the biodiversity significance of the farms since low field adjacency implies cutting off the ecological unit of the organic farms and can expose higher portions of land to potential conventional agriculture neighbours. Moreover, the indicator of Share species presents the higher discrepancy between the farms grouped in the North, Centre and South of Italy due to the fact that the organic farms under study in the North of Italy rear almost exclusively dairy cattle and the production appears to be quite intensive with rotations mainly between cultivations of corn and cereals.

The results concerning the only pig farm included in our study are strongly influenced by the location of the case study farm: located in the Padania's plain of Emilia-Romagna, where the general farm management is quite intensive, the farm present a quite simple structure as forest and woodland are not present in this flat land. However, over the rearing of pigs and cattle, the arable land of this farm has on average a three year crop rotation of green manure for vegetables, cereals and forage grass.

Since the indicators have been clustered according to the ecosystem services they contribute to, our study has highlighted how livestock farms can provide stronger social, economic and ecological sustainability. Moreover, through the comparison with the indicator values of stockless farms [54] our study highlighted how livestock farms could actually provide different ecosystem services in comparison to stockless farms. For instance, the significantly larger presence of woodland in livestock farms in comparison to stockless farms suggests more suitable conditions for the development of associated biodiversity, as also suggested by the larger presence of ecological infrastructures [55]. Furthermore, the management of local livestock breeds play a crucial role in maintaining genetic resources, reviving the connected pool of local knowledge and practises, as well as peculiar biocultural landscapes. Eventually the selected indicators were able to highlight how livestock farms tend to have a closed nitrogen cycle management due to self-production of manure and 
large percentages of leguminous crops and therefore provide a circularity of organic matter and agricultural produce that cannot be achieved as such in stockless farms.

From a social and economic point of view, mixed and multifunctional farms that entail the presence of animals present a higher diversification of products and sources of income that could ensure a higher resilience to the farm. For instance, the pig farm under study also sells mixed vegetable and fruit boxes directly to local consumers, and is officially recognized from the Region as a didactic farm.

\section{Conclusions}

This study proposes an innovative set of agroecological indicators to assess the state of structural/planned agrobiodiversity in livestock farming systems. The set of indicators has been clustered with respect to the ecosystem services they describe. The assessment of agricultural diversity of the farms under study showed remarkably positive results, satisfying almost all agroecological indicators desired values. The farms under study resulted in practicing agroecological mixed farming strategies that, as our results showed, are able to benefit the environment within and surrounding the farm as well as to play a role in alleviating biophysical and socio-economic constraints.

Author Contributions: Conceptualization, P.M. (Paola Migliorini); methodology, P.M. (Paola Migliorini); validation, C.F.B. and P.M. (Paolo Merante); data curation, S.R.B. and P.M. (Paolo Merante); writingoriginal draft preparation, C.F.B. and P.M. (Paola Migliorini); writing-review and editing, C.F.B. and P.M. (Paolo Merante); funding acquisition, C.V. All authors have read and agreed to the published version of the manuscript.

Funding: This research was partly funded by Regione Marche (Italy) in the framework of a research project on organic livestock within the Programma Interregionale III fase "Sviluppo rurale", sottoprogetto "Innovazione e Ricerca", in the period 2005-2008, title "Efficienza, Qualità e Innovazione nella Zootecnia Biologica" (E.QU.I.ZOO.BIO.). More recently it was partly supported by EU H2020 NEXTFOOD project "Educating the next generation of professionals in the agrifood system" - Call: Rural Renaissance-Fostering Innovation and Business Opportunities, Topic: RUR-13-2017 Building a future science and education system fit to deliver to practice-Grant agreement: No 771738.

Institutional Review Board Statement: The study was conducted in accordance with the Declaration of Helsinki, and approved by the Ethics Committee of University of Gastronomic Science (art. 2, com. a 18/09/2019).

Informed Consent Statement: Informed consent has been obtained from the farmers to publish this paper.

Data Availability Statement: Data are stored anonymity according to MDPI Research Data Policies.

Conflicts of Interest: The authors declare no conflict of interest. The funders had no role in the design of the study; in the collection, analyses, or interpretation of data; in the writing of the manuscript, or in the decision to publish the results.

\section{References}

1. Layman, D.K. Assessing the Role of Cattle in Sustainable Food Systems. Nutr. Today 2018, 53, 160-165. [CrossRef]

2. Dumont, B.; Groot, J.C.J.; Tichit, M. Review: Make ruminants green again-How can sustainable intensification and agroecology converge for a better future? Animal 2018, 12, s210-s219. [CrossRef] [PubMed]

3. Eisler, B.M.; Mark, C.; Lee, M.R.F.; Tartlon, J.F. Steps to sustainable livestock. Nature 2014, 507, 6. [CrossRef] [PubMed]

4. Martin, G.; Barth, K.; Benoit, M.; Brock, C.; Destruel, M.; Dumont, B.; Grillot, M.; Hübner, S.; Magne, M.-A.; Moerman, M.; et al. Potential of multi-species livestock farming to improve the sustainability of livestock farms: A review. Agric. Syst. 2020, 181, 102821. [CrossRef]

5. Gill, M.; Gibson, J.P.; Lee, M. Livestock production evolving to contribute to sustainable societies. Animal 2018, 12, 1696-1698. [CrossRef]

6. Sundrum, A. Organic livestock farming: A critical review. Livest. Prod. Sci. 2001, 67, 207-215. [CrossRef]

7. Prudhomme, R.; Brunelle, T.; Dumas, P.; Le Moing, A.; Zhang, X. Assessing the impact of increased legume production in Europe on global agricultural emissions. Reg. Environ. Chang. 2020, 20, 91. [CrossRef]

8. Wezel, A.; Casagrande, M.; Celette, F.; Vian, J.-F.; Ferrer, A.; Peigné, J. Agroecological practices for sustainable agriculture. A review. Agron. Sustain. Dev. 2014, 34, 1-20. [CrossRef] 
9. Kazemi, H.; Klug, H.; Kamkar, B. New services and roles of biodiversity in modern agroecosystems: A review. Ecol. Indic. 2018, 93, 1126-1135. [CrossRef]

10. Dalsgaard, J.; Oficial, R. A quantitative approach for assessing the productive performance and ecological contributions of smallholder farms. Agric. Syst. 1997, 55, 503-533. [CrossRef]

11. Parris, K. Environmental indicators for agriculture: Overview in OECD countries. In Environmental Indicators and Agricultural Policy; CABI: Oxford, UK, 1999; pp. 25-44. [CrossRef]

12. López-Ridaura, S.; Masera, O.; Astier, M. Evaluating the sustainability of complex socio-environmental systems. The MESMIS framework. Ecol. Indic. 2002, 2, 135-148. [CrossRef]

13. van der Werf, H.M.; Petit, J. Evaluation of the environmental impact of agriculture at the farm level: A comparison and analysis of 12 indicator-based methods. Agric. Ecosyst. Environ. 2002, 93, 131-145. [CrossRef]

14. Certomà, C.; Migliorini, P. The Evaluation of Sustainability of Organic Farms in Tuscany. In Survival and Sustainability; Springer: Berlin/Heidelberg, Germany, 2011; pp. 165-177. [CrossRef]

15. Nemecek, T.; Dubois, D.; Huguenin-Elie, O.; Gaillard, G. Life cycle assessment of Swiss farming systems: I. Integrated and organic farming. Agric. Syst. 2011, 104, 217-232. [CrossRef]

16. Peano, C.; Migliorini, P.; Sottile, F. A methodology for the sustainability assessment of agri-food systems: An application to the Slow Food Presidia project. Ecol. Soc. 2014, 19, 24. [CrossRef]

17. Caporali, F.; Mancinelli, R.; Campiglia, E. Indicators of Cropping System Diversity in Organic and Conventional Farms in Central Italy. Int. J. Agric. Sustain. 2003, 1, 67-72. [CrossRef]

18. Tasser, E.; Rüdisser, J.; Plaikner, M.; Wezel, A.; Stöckli, S.; Vincent, A.; Nitsch, H.; Dubbert, M.; Moos, V.; Walde, J.; et al. A simple biodiversity assessment scheme supporting nature-friendly farm management. Ecol. Indic. 2019, 107, 105649. [CrossRef]

19. Migliorini, P.; Vazzana, C. Biodiversity Indicators for Sustainability Evaluation of Conventional and Organic Agro-ecosystems Ital. J. Agron. 2007, 2, 105-110. [CrossRef]

20. Blumetto, O.; Castagna, A.; Cardozo, G.; García, F.; Tiscornia, G.; Ruggia, A.; Scarlato, S.; Albicette, M.M.; Aguerre, V.; Albin, A Ecosystem Integrity Index, an innovative environmental evaluation tool for agricultural production systems. Ecol. Indic. 2019, 101, 725-733. [CrossRef]

21. Nicholls, C.I.; Altieri, M.A.; Dezanet, A.; Lana, M.; Feistauer, D.; Ouriques, M. A rapid, farmer-friendly agroecological method to estimate soil quality and crop health in vineyard systems. Biodynamics 2004, 33-40. Available online: http://agroecology. pbworks.com/f/biodyn-indicators.pdf (accessed on 11 December 2021).

22. Funes-Monzote, F.R.; Monzote, M.; Lantinga, E.A.; Ter Braak, C.J.F.; Sanchez, J.E.; Van Keulen, H. Agro-Ecological Indicators (AEIs) for Dairy and Mixed Farming Systems Classification: Identifying Alternatives for the Cuban Livestock Sector. J. Sustain. Agric. 2009, 33, 435-460. [CrossRef]

23. Jeanneret, P.; Baumgartner, D.U.; Knuchel, R.F.; Koch, B.; Gaillard, G. An expert system for integrating biodiversity into agricultural life-cycle assessment. Ecol. Indic. 2014, 46, 224-231. [CrossRef]

24. Kok, A.; de Olde, E.M.; de Boer, I.; Ripoll-Bosch, R. European biodiversity assessments in livestock science: A review of research characteristics and indicators. Ecol. Indic. 2020, 112, 105902. [CrossRef]

25. FAO. Sustaining the Multiple Functions of Agricultural Biodiversity. Background Paper 1: Agricultural Biodiversity FAO/Netherlands Conf. Multifunct. Character Agric. L 1999, 1-41. Available online: https://www.jstor.org/stable/resrep01730 ?seq=1\#metadata_info_tab_contents (accessed on 11 December 2021).

26. Zimmerer, K.S.; de Haan, S.; Jones, A.D.; Creed-Kanashiro, H.; Tello, M.; Carrasco, M.; Meza, K.; Amaya, F.P.; Cruz-Garcia, G.S.; Tubbeh, R.; et al. The biodiversity of food and agriculture (Agrobiodiversity) in the anthropocene: Research advances and conceptual framework. Anthropocene 2019, 25, 100192. [CrossRef]

27. Overmars, K.P.; Schulp, N.; Alkemade, R.; Verburg, P.H.; Temme, A.; Omtzigt, N.; Schaminée, J.H. Developing a methodology for a species-based and spatially explicit indicator for biodiversity on agricultural land in the EU. Ecol. Indic. 2014, 37, 186-198. [CrossRef]

28. Vandermeer, J.H. The Ecology of Agroecosystems; Jones and Bartlett Publishers: Sudbury, MA, USA, 2011.

29. Daily, G.; Matson, P.A.; Costanza, R.; Nabhan, G.P.; Lubchenco, J. What are ecosystem services? In Nature's Services: Societal Dependence on Natural Ecosystems. Island Press: Washington, DC, USA, 1997; pp. 7-8.

30. Millennium Ecosystem Assessment. Ecosystems and Human Well-Being: Synthesis; Island Press: Washington, DC, USA, 2005.

31. Nicholls, C.I.; Altieri, M.A. Pathways for the amplification of agroecology. Agroecol. Sustain. Food Syst. 2018, $42,1170-1193$. [CrossRef]

32. Labeyrie, V.; Antona, M.; Baudry, J.; Bazile, D.; Bodin, Ö.; Caillon, S.; Leclerc, C.; Le Page, C.; Louafi, S.; Mariel, J.; et al. Networking agrobiodiversity management to foster biodiversity-based agriculture. A review. Agron. Sustain. Dev. 2021, 41, 4. [CrossRef]

33. Luna-González, D.V.; Sørensen, M. Higher agrobiodiversity is associated with improved dietary diversity, but not child anthropometric status, of Mayan Achí people of Guatemala. Public Health Nutr. 2018, 21, 2128-2141. [CrossRef] [PubMed]

34. Oduor, F.O.; Boedecker, J.; Kennedy, G.; Termote, C. Exploring agrobiodiversity for nutrition: Household on-farm agrobiodiversity is associated with improved quality of diet of young children in Vihiga, Kenya. PLoS ONE 2019, 14, e0219680. [CrossRef]

35. Ciaccia, C.; La Torre, A.; Ferlito, F.; Testani, E.; Battaglia, V.; Salvati, L.; Roccuzzo, G. Agroecological Practices and Agrobiodiversity: A Case Study on Organic Orange in Southern Italy. Agronomy 2019, 9, 85. [CrossRef] 
36. Radović, Č.; Gogić, M.; Radojković, D.; Živković, V.; Parunović, N.; Stanojković, A.; Savić, R. Agro biodiversity and livestock farming: Autochthonous species and breeds in Serbia. Proc. 12th Int. Symp. 2019, 2, 1-12.

37. Vereijken, P. A methodical way of prototyping integrated and ecological arable farming systems (I/EAFS) in interaction with pilot farms. Eur. J. Agron. 1997, 7, 235-250. [CrossRef]

38. Migliorini, P. Evaluation of Sustainability in Organic System and Fields of Tuscany; University of Florence: Florence, Italy, 2006.

39. Pacini, C.; Lazzerini, G.; Migliorini, P.; Vazzana, C. An Indicator-Based Framework to Evaluate Sustainability of Farming Systems: Review of Applications in Tuscany. Ital. J. Agron. 2009, 4, 23-40. [CrossRef]

40. Altieri, M.A. The ecological role of biodiversity in agroecosystems. Agric. Ecosyst. Environ. 1999, 74, 19-31. [CrossRef]

41. Herzog, F.; Balázs, K.; Dennis, P. Biodiversity Indicators for European Farming Systems. A Guidebook. ART Schr. 2012, 17, 1-104.

42. Fahrig, L.; Baudry, J.; Brotons, L.; Burel, F.G.; Crist, T.O.; Fuller, R.J.; Sirami, C.; Siriwardena, G.M.; Martin, J.L. Functional landscape heterogeneity and animal biodiversity in agricultural landscapes. Ecol. Lett. 2011, 14, 101-112. [CrossRef]

43. Anonymous. Commission regulation (EC) no 889/2008 of 5 September 2008 laying down detailed rules for the implementation of council regulation (EC) no 834/2007 on organic production and labelling of organic products with regard to organic production, labelling and co. Off. J. Eur. Union 2008, 250, 1-84.

44. Fahrig, L.; Girard, J.; Duro, D.; Pasher, J.; Smith, A.; Javorek, S.; King, D.; Lindsay, K.F.; Mitchell, S.; Tischendorf, L. Farmlands with smaller crop fi elds have higher within- fi eld biodiversity. Agric. Ecosyst. Environ. 2015, 200, 219-234. [CrossRef]

45. Jax, K. Ecological Units: Definitions and Application. Q. Rev. Biol. 2006, 81, 237-258. [CrossRef]

46. Du, R.; Ernoult, A.; Aviron, S.; Fahrig, L.; Burel, F. Relative effects of landscape composition and con fi guration on multi-habitat gamma diversity in agricultural landscapes. Agric. Ecosyst. Environ. 2017, 241, 62-69.

47. Batáry, P.; Matthiesen, T.; Tscharntke, T. Landscape-moderated importance of hedges in conserving farmland bird diversity of organic vs. conventional croplands and grasslands. Biol. Conserv. 2010, 143, 2020-2027. [CrossRef]

48. FAO. Sustainability Pathways: Evaluaciónes de la Sostenibilidad. SAFA. 2014. Available online: https://www.fao.org/ $\mathrm{nr} /$ sustainability/evaluaciones-de-la-sostenibilidad-safa/httpwwwfaoorgnrsustainabilityevaluaciones-de-la-sostenibilidadsafasafa-usagees/es/ (accessed on 11 December 2021).

49. Redlich, S.; Martin, E.A.; Wende, B.; Steffan-Dewenter, I. Landscape heterogeneity rather than crop diversity mediates bird diversity in agricultural landscapes. PLoS ONE 2018, 13, e0200438. [CrossRef] [PubMed]

50. Biodiversity International. The Agrobiodiversity Index Methodology Report v.1.0. 2018. Available online: https://cgspace.cgiar org/handle/10568/106478 (accessed on 20 November 2021).

51. Torralba, M.; Fagerholm, N.; Hartel, T.; Moreno, G.; Plieninger, T. A social-ecological analysis of ecosystem services supply and trade-offs in European wood-pastures. Sci. Adv. 2018, 4, 2176. [CrossRef] [PubMed]

52. Tamburini, G.; Bommarco, R.; Wanger, T.C.; Kremen, C.; van der Heijden, M.G.A.; Liebman, M.; Hallin, S. Agricultural diversification promotes multiple ecosystem services without compromising yield. Sci. Adv. 2020, 6, eaba1715. [CrossRef] [PubMed]

53. European Union. Agrienvironmental Indicator-Livestock Patterns. 2017. Available online: https://ec.europa.eu/eurostat/ statistics-explained/index.php?title=Agri-environmental_indicator_-_livestock_patterns (accessed on 12 December 2021).

54. Migliorini, P.; Galioto, F.; Chiorri, M.; Vazzana, C. An integrated sustainability score based on agro-ecological and socioeconomic indicators. A case study of stockless organic farming in Italy. Agroecol. Sustain. Food Syst. 2018, 42, 859-884. [CrossRef]

55. Kremen, C.; Miles, A. Ecosystem Services in Biologically Diversified versus Conventional Farming Systems: Benefits, Externalities, and Trade-Offs. Ecol. Soc. 2012, 17, 40. [CrossRef] 